Quebec Cooperative Study of Friedreich's Ataxia

\title{
Pilot Study of Threonine Supplementation in Human Spasticity
}

\author{
A. BARBEAU, M. ROY, C. CHOUZA
}

\begin{abstract}
Threonine supplementation (500 $\mathrm{mg} /$ day) was given to 6 patients with genetic spasticity syndromes for a period of 12 months, followed by a 4-month observation period without medication. All 6 patients showed partial improvement of spasticity, intensity of knee jerks and muscle spasms without changes in true pyramidal tract signs. The improvement in motor performance, objectively measured, averaged $29 \%$ (19\% in upper limbs and $42 \%$ in lower limbs). The range of overall
\end{abstract}

RÉSUMÉ: Nous avons donné un supplément oral de thréonine $(500 \mathrm{mg} / \mathrm{jour})$ à 6 patients souffrant de syndromes spastiques génétiques, et ce pour une période de 12 mois, suivie d'une période d'observation de 4 mois sans médication. Tous les patients ont noté une amélioration partielle de la spasticité, de l'intensité des réflexes ostéotendineux du genou, et des spasmes musculaires, sans modification des véritables signes pyramidaux. L'amélioration objective de la performance motrice est en improvement was $19-35 \%$ (7-30\% for upper limbs; $25-67 \%$ for lower limbs). No toxic clinical or biochemical side effects were encountered. Thus threonine, a precursor of glycine, produced the same effect on spasticity than that previously observed with glycine. It is concluded that threonine supplementation is feasible and safe and that it deserves a controlled trial in well defined (preferably genetic) cases of spasticity.

moyenne de $29 \%$ après un an (19\% aux membres supérieurs et $42 \%$ aux membres inférieurs). La fourchette statistique de l'amélioration globale était de 19 à 35\% (7$30 \%$ pour les membres supérieurs; $25-67 \%$ pour les membres inférieurs). Nous n'avons observé aucun effet toxique clinique ou biochimique. Il semble donc que la thréonine, un précurseur de la glycine, produise le même effet anti-spastique que celui observé préalablement avec la glycine.
From the Department of Neurobiology Clinical Research Institute of Montreal.

Reprint Requests for the complete supplement on Friedreich's Ataxia (Phase Three, Part Two) to: Prof André Barbeau, Clinical Research Institute of Montreal, 110 Pine Avenue West, Montréal, Quebec, Canada, H2W $1 \mathrm{R} 7$.

\section{INTRODUCTION}

Spasticity, according to Young and Delwaide's important review (1981), has been defined as "a motor disorder characterized by a velocity-dependent increase in tonic stretch reflexes ("muscle tone") with exaggerated tendon jerks, resulting from hyperexcitability of the stretch reflex, as one component of the upper motor neuron syndrome". This definition does not encompass all the other symptoms listed by Landau (1974), such as flexor spasms, "weakness" and loss of dexterity. The latter two symptoms may be more incapacitating than "spasticity" itself. It is thus not surprising that most partially effective treatments of spasticity (diazepam, baclofen and dantrolene) do not specifically help the stretch reflexes, but act mainly on these secondary symptoms (Young and Delwaide, 1981; Feldman et al, 1980).

The pathophysiology of spasticity is still a subject of controversy. Many authors believe there is a loss of central modulation of afferent inputs in the spinal cord segmental inhibitory processes regulating spinal reflex activity (Roberts, 1974). Both presynaptic and postsynaptic segmental inhibitory systems can be suppressed in spasticity, (Burke and Ashby, 1972). Studies from the laboratories of Aprison and Werman have shown that the amino-acid glycine may mediate post synaptic inhibition, thus having an important role in the spinal cord (Aprison and Werman, 1965; Aprison et al, 1969; Aprison and Nadi, 1978; Werman et al, 1968). More recent studies reviewed by Pycock and Kerwin (1981) indicate also that glycine may have more than a metabolic role at supraspinal sites within the central nervous system. Specific regions include 
the substantia nigra, optic tectum, retina and neostriatum where it may interact with dopamine through specific glycine receptors (Levi et al, 1982; Gundlach and Beart, 1982; de Montis et al, 1982; Snyder, 1975).

In acute experimental spasticity in the dog, Hall et al (1976) found a decrease in the glycine content of spinal ventrocentral gray matter 8 weeks after spinal cord transection. In further studies Hall et al, (1979) determined the content and specific activity of glycine and serine in feline spastic spinal cord, following the intra-aortic administration of two labelled precursors of glycine: ${ }^{14} \mathrm{C}$-D-glucose and ${ }^{14}$ $C$-L-serine. The specific activities of both glycine and serine were significantly reduced in the ventromedial, central and dorsal spinal gray matter in spastic animals. Glycine content remained at control values but serine content increased in spastic spinal cord. The authors conclude that glycine turnover is decreased in spasticity, owing to its diminished release. Boehme et al, (1976) also confirmed that glycine levels were normal in the degenerated human spinal cord.

The next step was obvious and was first verified in rats. In 1970, Stern and Hadzovic injected glycine in rats and noted a decrease in the experimental hindlimb rigidity. This was confirmed in dogs by Smith et al (1979). After 50 $\mathrm{mg} / \mathrm{kg}$ per day of glycine, some of the clinical signs of spasticity improved in the animals injected with glycine compared to the saline-injected controls. The content of glycine was significantly elevated in the central gray matter and ventral medial white matter of the glycine-treated dogs. The clinical signs helped in dogs by glycine were tone, extensor spasms and scissoring of the hindlimbs. The authors conclude that exogenous glycine might increase segmental spinal postsynaptic inhibition either directly, by interacting with post synaptic glycinergic receptors, or indirectly, by stimulating the presynaptic release of glycine from glycinergic inhibitory neurons.

Based on these experimental studies, two groups simultaneously investigated the possible use of glycine in humans. Barbeau (1974) studied 10 patients with marked spasticity of both legs ( 7 with chronic multiple sclerosis; 2 with familial spastic paraplegia and one with the spasticity of pernicious anemia). Each patient received $1 \mathrm{gm}$ of glycine daily ( $250 \mathrm{mg}$, four times a day) orally for periods of at least six months. Spasticity was evaluated through graded neurologic examinations, a number of scales and a battery of tests measuring motor performance. No toxicity of any kind was reported. Overall improvement in spasticity and mobility of the lower limbs was 25 percent, but no change in other neurologic signs (Babinski, tendon reflexes) was noted. All patients had some level of improvement. Similar results were reported in seven patients by Stern and Bokonjic (1974).

The above studies, although encouraging, were incomplete for many reasons: no double-blind evaluation was performed; only one dose of the amino-acid was tested, with no evidence that this was the optimal dosage for clinical use; the main drawback resided in the heterogeneity of the patient population. It is evident that the spasticity from a cerebrovascular accident, from trauma, or from multiple sclerosis could well have different pathogenetic mechanisms, and therefore different biochemical causes. Further testing of the hypothesis with controlled studies still awaits the long process of clearance for long-term human administration of glycine. In such studies it will be imperative to choose a group of patients with essentially the same process, even if from different causes. Selecting patients with genetic forms of spasticity may partially help to resolve the dilemna.

Giving glycine orally may eventually permit incorporation of that aminoacid into presynaptic terminals and favour synaptic release, but a better effect could be expected from the use of precursors of glycine. This concept was developed by us for dopamine, and LDOPA (Barbeau, 1961), and for many other amino-acids by Wurtman and his group (1974; see also Wurtman, 1982 and Barbeau et al, 1979 for reviews). The principal metabolic precursors of glycine appear to be serine and glucose (Aprison and Nadi, 1978). In the brain, and probably also in the spinal cord, there is a preferential conversion of serine to glycine (McBride et al, 1973). However, if this is true for the metabolic pool, the evidence for serine as a precursor of neurotransmitter glycine is not as strong. Indeed some behavior effects of serine indicate that conversion to glycine may not be the preferred mechanism (Glyn and Lipton, 1980). No correlation exists between serine and glycine levels in the CNS and in preliminary studies (Barbeau, 1976, unpublished), we could not demonstrate an effect of serine supplementation in human spasticity.

Recently threonine was proposed as a possible precursor of glycine. In 1979 and 1980 Maher and Wurtman reported that administration of L-Threonine to rats increased the glycine content in cord and brain. This was confirmed by Siemers et al. (1980) who showed that a linear relationship existed between the levels of threonine and glycine in 10 sub-areas of the rat medulla cut coronally, as well as 8 major areas of the rat neuroaxis (telencephalon through grey and white spinal cord). The data from both laboratories suggest that a portion of the threonine pool in rat CNS is converted to glycine.

Threonine is an essential amino-acid which can be derived from homoserine. A threonine requirement of $6.8 \mathrm{mg}$ per $\mathrm{kg}$ per 24 hours for young men, and 7.6 mg per kg per 24 hours for elderly subjects has been calculated (Tontisirin et al, 1974). Signs of neurologic dysfunction and/or lameness developed in 14 of 17 kittens fed threonine-imbalanced or deficient diets, which resolved as dietary threonine was increased (Titchenal et al, 1980). It was therefore decided to test the hypothesis that the amino-acid threonine could serve as a precursor of glycine and modify the symptoms of spasticity in patients with genetic forms of the disease, therefore presumably clinically homogeneous. The present paper constitutes a report of the preliminary phases of this investigation, which was initiated after consultation with Drs. John H. Growdon and Richard J. Wurtman of Boston who collaborated in the initial hypothesis.

\section{SUBJECTS AND METHODS}

Subjects chosen for the study were all victims of genetic forms of spastici- 
ty. Four were women, two men; average age 29.7 yrs. Two patients suffered from a recessive form of familial spastic paralysis with major involvement of the lower limbs and no ataxia. Upper limbs were essentially normal. Two patients, slightly more involved than the preceding two, suffered from a recessive form of spastic ataxia. In these patients lower limb spasticity was accompanied by an ataxic gait and by some minor degree of upper limb dysmetria and adiadocokinesia. For a review of the classification of the various recessive ataxic and spastic syndromes see Barbeau (1982, this issue). Finally 2 patients were victims of the Charlevoix-Saguenay Syndrome of spastic ataxia (Bouchard et al, 1978). In these subjects a fairly severe peripheral neuropathy was present, accompanied by upper limb ataxia and dysarthria in addition to truncal ataxia.

All patients gave informed consent to the experimental trial and permission was obtained from the Ethics committees of the Institute and of the HôtelDieu Hospital. Threonine was purchased from Ajinomoto Co. Inc., K yobashi, Tokyo, Japan and prepared in gelatin capsules of $250 \mathrm{mg}$. The protocol included an initial 3-weeks stay in our hospital metabolic unit, during which threonine was increased gradually to tolerance, or to a maximum of 2.5 grams per day. To avoid artefactual improvement, a physiotherapy regimen was not given to our patients as we would normally do. During this hospitalization blood and urine biochemical parameters were monitered. The patients underwent mechanical performance testing every week, with three control values obtained before drug treatment (at 2 day intervals). The battery utilized for motor performance evaluation has been in use in our laboratory for 20 years (Dery et al, 1962).

Upon discharge from hospital the dosage of threonine was gradually decreased over the next 2 months to $500 \mathrm{mg} /$ day in most patients (range 500$1000 \mathrm{mg} / \mathrm{day}$ ) and maintained at this dose for the next 9 months. At the end of one year of treatment, threonine supplementation was stopped and the patients observed for a further 4 months without any treatment.

\section{RESULTS AND DISCUSSION}

The results of the neurological evaluation before treatment, and after one year of threonine supplementation are listed in Table 1.

It can be seen that, at time 0 , all patients had brisk knee jerks, Babinski signs and marked spasticity in the lower limbs including ankle clonus. Some also had severe spasms and still others, particularly the patients with the Charlevoix-Saguenay Syndrome, ataxia. Treatment with threonine clearly reduced the strength of the knee jerks in all patients (approximately 2-3 months after initiation of the treatment) and the number and intensity of the muscle spasms. Similarly, spasticity in the lower limbs was decreased. On the other hand there were no changes in the presence of the Babinski sign nor in ataxia.

Two patients experienced episodes of dizziness ("giddiness") in the early phase of treatment, and 3 suffered from occasional nausea. No other symptoms could be associated with the treatment. Blood analysis (SMA-15, $\mathrm{Hb}, \mathrm{Ht}$, WBC count and blood smear) remained unchanged throughout the trial.

Objective results are expressed as absolute scores in Table 2.

It can thus be seen that the least affected patients (as far as motor performance is concerned) are the two women with familial spastic paralysis. The most affected are the patients with the Charlevoix-Saguenay syndrome of spastic ataxia. Improvement in overall motor performance was noted in all patients, but varied from 19 to $35 \%$. In general the improvement was most noticeable in the lower limbs, where spasticity was more severe to start with. It can also be seen in Table 2, that most scores tended to retrogress after cessation of treatment. The overall motor performance after 12 months of threonine supplementation had been $29 \%$ (19\% upper limbs and $42 \%$ lower limbs), but it decreased to $17 \%(13 \%$ U.L.; $24 \%$ L.L.) four months after cessation of treatment.

These results appear to be real and more than a placebo effect because of

TABLE 1

CHANGES IN NEUROLOGICAL SIGNS AFTER 12 MONTHS OF THREONINE IN SPASTIC PATIENTS

\begin{tabular}{cccc} 
Patient No. & \multicolumn{2}{c}{ Knee Jerk } \\
& Month: & 0 & 12 \\
1 & FSP & +++ & ++ \\
2 & FSP & +++ & + \\
3 & RSA & +++ & ++ \\
4 & RSA & ++++ & ++ \\
5 & CSS & +++ & + \\
6 & CSS & ++++ & ++
\end{tabular}

\begin{tabular}{lr}
\multicolumn{2}{c}{ Babinski } \\
0 & 12 \\
+ & + \\
+ & + \\
+ & + \\
+ & + \\
+ & + \\
+ & +
\end{tabular}

\begin{tabular}{ll}
\multicolumn{2}{c}{ Spasms } \\
0 & 12 \\
- & - \\
+ & - \\
+ & - \\
+ & - \\
+ & +
\end{tabular}

\begin{tabular}{cc}
\multicolumn{3}{l}{ L.L. Spasticity } \\
and clonus \\
0 & 12 \\
++ & + \\
++ & + \\
+++ & ++ \\
+++ & ++ \\
+++ & ++ \\
+++ & +++
\end{tabular}

\begin{tabular}{ll}
\multicolumn{2}{c}{ Ataxia } \\
0 & 12 \\
- & - \\
- & - \\
+ & - \\
++ & + \\
++ & ++
\end{tabular}

See Legend on Table 2 
TABLE 2

EFFECT OF THREONINE TREATMENT ON MOTOR PERFORMANCE IN SPASTIC PATIENTS (\% CHANGE) - INDIVIDUAL SCORES

\begin{tabular}{|c|c|c|c|c|c|c|c|c|c|c|c|}
\hline \multicolumn{3}{|c|}{ Patients } & \multicolumn{3}{|c|}{\begin{tabular}{|c|} 
Highest \\
Pre-Treatment \\
Scores
\end{tabular}} & \multicolumn{3}{|c|}{$\begin{array}{l}\text { after } 12 \text { Months } \\
\text { Treatment }\end{array}$} & \multicolumn{3}{|c|}{$\begin{array}{l}\text { Scores } 4 \text { Months } \\
\text { Post Treatment }\end{array}$} \\
\hline No.Type & Sex & Age & U.L. & L.L. & Total & U.L. (\%) & L.L. (\%) & Total (\%) & U.L. (\%) & L.L. (\%) & Total (\%) \\
\hline 1 FSP & $\mathrm{F}$ & 27 & 435 & 310 & 745 & $533(23)$ & $456(47)$ & $989(33)$ & $498(14)$ & $417(35)$ & $915(23)$ \\
\hline 2 FSP & $\mathrm{F}$ & 30 & 400 & 217 & 617 & $522(30)$ & $313(44)$ & $835(35)$ & $480(2)$ & $281(29)$ & $761(23)$ \\
\hline 3 RSA & $\mathbf{M}$ & 28 & 366 & 388 & 754 & $448(22)$ & $490(26)$ & $938(24)$ & $469(28)$ & $436(12)$ & $895(19)$ \\
\hline 4 RSA & $\mathrm{F}$ & 30 & 302 & 216 & 518 & $368(22)$ & $308(43)$ & $676(31)$ & $338(12)$ & $288(33)$ & $626(21)$ \\
\hline $5 \mathrm{CSS}$ & M & 28 & 296 & 194 & 490 & $318(7)$ & $324(67)$ & $642(31)$ & $270(-9)$ & $239(23)$ & $509(4)$ \\
\hline $6 \mathrm{CSS}$ & $\mathrm{F}$ & 35 & 249 & 142 & 381 & $274(10)$ & $177(25)$ & $453(19)$ & $274(10)$ & $157(10)$ & $433(14)$ \\
\hline
\end{tabular}

Normal scores: $>400>400>800$

LEGEND: FSP: Familial Spastic Paralysis (recessive)

RSA: Recessive Spastic Ataxia

CSS: Charlevoix-Saguenay Syndrome

U.L.: Upper Limbs

L.L.: Lower Limbs

the long period of observation. No double-blind design was accepted by our Ethics Committee, because this was the very first use of threonine in humans, and it was felt important to keep all options immediately open for this pilot study. Although threonine seems to decrease spasm, knee jerks and spasticity of genetic origin in the majority of patients treated, there were no changes observed in true pyramidal tract signs (Babinski) nor in ataxia, when it was present. The reappearance of the other signs after cessation of threonine is an added indication of a real effect.

In conclusion, we can state that in a an open pilot study, threonine supplementation was able to objectively improve motor performance, particularly in the lower limbs, and to reduce spasticity, painful muscle spasms and hyperactive knee jerks. We can further state that long-term use of low doses of threonine appears to be devoid of serious clinical or biochemical sideeffects. However, at this stage, we cannot claim any therapeutic success. It must be recalled that we still do not know the optimal dose to administer and that in none of the patients were reversal to normal states produced. Nevertheless the significant reducing effect on spasticity of threonine observed in the study indicates that controlled studies are safe and warranted. Again we stress the need to utilize patients with well defined homogeneous and preferably genetic, syndromes of spasticity to test this possible drug effect.

\section{ACKNOWLEDGEMENTS}

These studies were supported by grants from l'Association Canadienne de l'Ataxie de Friedreich, the $O$. Mallette Foundation of the Hôtel-Dieu Hospital and the Ministry of Health and Welfare (Ottawa). The authors would like to extend special thanks to Drs. J.H. Growdon and R.J. Wurtman of Boston for the stimulation and help they gave to these studies, and for the initial gift of threonine. We want also to thank Miss D. Bédard and Miss S. Paris for nursing help, as well as Mrs. Hélène L. Crête for typing the manuscript. Dr. C. Chouza was on leave from the University of Uruguay in Montevideo.

\section{REFERENCES}

APRISON, M.H. and NADI, N.S. (1978). Glycine: inhibition from the sacrum to the medulla. in Amino acids as chemical trans- mitters. Ed. by F. Fonnum. Plenum Press pp. 531-570.

APRISON, M.H.; SHANK, R.P. and DAVIDOFF, R.A. (1969). A comparison of the concentration of glycine, a transmitter suspect, in different areas of the brain and spinal cord in seven different vertebrates. Comp. Biochem. Physiol. 28: 1345-1355.

APRISON, M.H. and WERMAN, R. (1965). The distribution of glycine in cat spinal cord and roots. Life Sci. 4: 2075-2083.

BARBEAU, A. (1961). Biochemistry of Parkinson's disease. Excerpta Medica, I.C.S. 38: 152-153.

BARBEAU, A. (1974). Preliminary study of glycine administration in Patients with spasticity. Neurology 24: 392.

BARBEAU, A., GROWDON, J.H. and WURTMAN, R.J., Eds. (1979). Nutrition and the Brain, Vol. 5 Raven Press, New York.

BOEHME, D.H., MARKS, N. and FORDICE, M.W. (1976). Glycine levels in the degenerated human spinal cord. J. Neurol. Sci. 27: $347-352$.

BOUCHARD, J.P.; BARBEAU, A. BOUCHARD, R. and BOUCHARD, R.W. (1978). Autosomal recessive spastic ataxia of Charlevoix-Saguenay. Can. J. Neurol. Sci. 5: 61-69. 
BURKE, D. and ASHBY, P. (1972). Are spinal "presynaptic" inhibitory mechanisms suppressed in spasticity? J. Neurol. Sci. 15: $321-326$.

DE MONTIS, G., BEAUMONT, K., JAVOYAGID, F., AGID, Y., CONSTANDINIDIS, J., LOWENTHAL, A. and LLOYD, K.G. (1982). Glycine receptors in the human substantia nigra as defined by $\left[\mathrm{H}^{3}\right]$ strychnine binding. J. Neurochem. 38: 718-724.

DERY, J.P., De GROOT, J.A., LAURIN, C. and BARBEAU, A. (1962). Nouvelle méthode d'évaluation objective de la rigidité et du tremblement dans la maladie de Parkinson. Union Méd. Can. 91: 842-847.

FELDMAN, R.G., YOUNG, R.R. and KOELLA, W.P. (Eds) (1980). Spasticity: disordered motor control. Chicago; Year Book Publishers.

GLYN, J.R. and LIPTON, J.M. (1980). Comparison of the effects of central administration of serine and glycine on body temperature of the rabbit. Brain Res. Bull. 5: 661-665.

GUNDLACH, A.L. and BEART, P.M. (1982). Neurochemical studies of the mesolimbic dopaminergic pathway: glycinergic mechanisms and glycinergic - dopaminergic interactions in the rat ventral tegmentum. J. Neurochem. 38: 574-581.

HALL, P.V., SMITH, J.E., CAMPBELL, R.L. (1976). Neurochemical correlates of spasticity. Life Sci. 18: 1467-1472.

HALL, P.V., SMITH, J.E., LANE, J., MOTE, T. and CAMPBELL, R. (1979). Glycine and experimental spinal spasticity. Neurology 29: 262-267.

LANDAU, W.M. (1974). Spasticity: the fable of a neurological demon and the emperor's new therapy. Arch. Neurol. 31: 217-219.

LEVI, G., BERNARDI, G., CHERUBINI, E., GALLO, V., MARCIANI, G. and STANZIONE, P. (1982). Evidence in favor of a neurotransmitter role of glycine in the rat cerebral cortex. Brain Res. 236: 121-131.

MAHER, T.J. and WURTMAN, R.J. (1979). L-Threonine and glycine in rat CNS. Neurosci. abs. 5: 593 .

MAHER, T.J. and WURTMAN, R.J. (1980) L-Threonine administration increases glycine concentrations in the rat central nervous system. Life Sci. 26: 1283-1286.

McBRIDE, W.J., DALY, E. and APRISON, M.H. (1973). Interconversion of glycine and serine in a synaptosome fraction isolated from the spinal cord, medulla oblongata, telencephalon and cerebellum of the rat. $J$. Neurochem. 4: 557-566.

PYCOCK, C.J. and KERWIN R.W. (1981) The status of glycine as a supra-spinal neurotransmitter - Minireview. Life Sciences 28: $2679-2686$

ROBERTS, E. (1974). Disinhibition as an organizing principle in the nervous system The role of gamma-aminobutyric acid. Adv. Neurol. 5: 127-143.

SIEMERS, E.R., DALY, E.C. and APRISON, M.H. (1980). Is threonine a precursor of one of the central pools of glycine? Amer. Soc. Neurochem. Abs. Vol. 11:69.
SMITH, J.E., HALL, P.V., GALVIN, M.R. JONES, A.R. and CAMPBELL, R.L. (1979). Effects of glycine adminstration on canine experimental spinal spasticity and the levels of glycine, glutamate, and aspartate in the lumbar spinal cord. Neurosurg. 4: 152156.

SNYDER, S.H. (1975). The glycine receptor in the mammalian central nervous system. $\mathrm{Br}$. J. Pharmacol. 53: 473-484.

STERN, P. and BOKONJIC, R. (1974). Glycine therapy in seven cases of spasticity. Pharmacology 12: 117-119.

STERN, P. and HADZOVIC, S. (1970). Effect of glycine on experimental hindlimbs rigidity in rats. Life Sci. 9: 955-959.

TITCHENAL, C.L., ROGERS, Q.R., INDRIERI, R.J. and MORRIS, J.G. (1980). Threonine imbalance, deficiency and neurologic dysfunction in the kitten. J. Nutr. 110: 2444-2459.

TONTISIRIN, K., YOUNG, V.R., RAND, M.W. and SCRIMSHAW, N.S. (1974). Plasma threonine response curve and threonine requirements of young men and elderly women. J. Nutrition. 104: 495-505.

WERMAN, R., DAVIDOFF, R.A. and APRISON, M.H. (1968). Inhibitory action of glycine on spinal neurons in the cat. J. Neurophysiol. 31: 81-95.

WURTMAN, R.J. (1982). Nutrients that modify brain function. Scientific American 246: 50-59.

YOUNG, R.R. and DELWAIDE, P.J. (1981). Spasticity. New Engl. J. Med. 304: 28-33, 96,99. 